\title{
Peran Pemasaran Kewirausahaan Dalam Meningkatkan Daya Saing Usaha Mikro Kecil dan Menengah di Kota Bandung
}

\author{
Fellyana Yuni Indrianti* dan Ermina Tiorida \\ Jurusan Administrasi Niaga, Politeknik Negeri Bandung, Indonesia
}

\begin{abstract}
:
Entrepreneurial marketing is word of mouth marketing which is usually done by the owner privately but informally. Word of mouth marketing is done directly by business owners to find customers directly and build interpersonal relationships with customers. Entrepreneurial marketing is carried out by micro small and medium business entrepreneurs in the city of Bandung because of limited marketing funds and limited business capital. This research was conducted to analyze the effect of entrepreneurial marketing on business competitiveness. The sample in this study were 170 respondents distributed using questionnaires. This research uses simple regression analysis and descriptive analysis. Based on the results of data processing it is known that entrepreneurial marketing has a positive and significant effect on competitiveness. The positive value (0.283) contained in the regression coefficient illustrates that the direction of the effect of entrepreneurial marketing variables on competitiveness is unidirectional, each addition of one unit of entrepreneurial marketing variables will increase the value of competitiveness variables by 0.283 .
\end{abstract}

Keywords: competitiveness, entrepreneurial marketing, micro small and medium enterprise

\begin{abstract}
Abstrak:
Pemasaran wirausaha adalah pemasaran dari mulut ke mulut yang biasanya dilakukan oleh pemilik secara pribadi tetapi informal. Pemasaran dari mulut ke mulut dilakukan langsung oleh pemilik bisnis untuk menemukan pelanggan secara langsung dan membangun hubungan interpersonal dengan pelanggan. Pemasaran kewirausahaan dilakukan oleh pelaku bisnis usaha mikro kecil dan menengah di Kota Bandung karena keterbatasan dana pemasaran dan modal usaha yang terbatas. Penelitian ini dilakukan untuk menganalisis pengaruh pemasaran kewirausahaan terhadap daya saing usaha. Sampel dalam penelitian ini adalah 170 responden yang disebarkan menggunakan kuesioner. Penelitian ini menggunakan analisis regresi sederhana dan analisis deskriptif. Berdasarkan hasil pengolahan data diketahui bahwa pemasaran wirausaha berpengaruh secara positif dan signifikan terhadap daya saing. Nilai positif $(0,283)$ yang terkandung dalam koefisien regresi menggambarkan bahwa arah pengaruh variabel pemasaran kewirausahaan terhadap daya saing adalah searah, setiap penambahan satu unit variabel pemasaran kewirausahaan akan meningkatkan nilai variabel daya saing sebesar 0,283 .
\end{abstract}

Kata kunci: daya saing, pemasaran kewirausahaan, usaha mikro kecil dan menengah

\section{Pendahuluan}

Indonesia merupakan negara berkembang yang sedang menggerakan perekonomian negara melalui Usaha Mikro Kecil (UMKM). UMKM mampu memberikan sumbangan terhadap perkembangan suatu negara (Rachma, 2015:11). Pada tahun 1997, Indonesia terbukti dapat bertahan pada saat krisis 
ekonomi. UMKM merupakan satu-satunya sektor perekonomian yang dapat bertahan karena sektor UMKM tidak mengandalkan barang impor sehingga tidak terpengaruh oleh krisis moneter (Tyas \& Safitri, 2014).

Di Kota Bandung terdapat dalam tiga sektor sentra industri kreatif utama dengan tujuh sentra kawasan industri utama. Tiga sektor industri kreatif terdiri atas kuliner, fashion, dan kerajinan. Tujuh kawasan industri utama terdiri atas sentra sepatu dan olahan kulit di Cibaduyut, sentra boneka di Sukamulya, sentra rajutan di Binong, serta sentra tahu dan tempe di Cibuntu, sentra perdagangan kain Cigondewah, Sentra Perdagangan Jeans Cihampelas. Salah satu sentra kawasan adalah sentra kawasan rajut di Binong yang menawarkan kerajinan tangan yang berupa produk rajutan yang dihasilkan adalah sweater rajut, syal, jaket, sarung tangan, dll. Sentra rajutan Binong beralamat di Jalan Binong Jati Kelurahan Binong Kecamatan Batununggal kota Bandung.

Tabel 1 Jumlah Pertambahan UMKM Berdasarkan Jenis Usaha Tahun 2012-2017

\begin{tabular}{|l|l|c|c|c|}
\hline \multirow{2}{*}{ No } & \multirow{2}{*}{ Jenis Usaha } & \multicolumn{3}{|c|}{ Tahun } \\
\cline { 3 - 5 } & & 2015 & 2016 & 2017 \\
\hline 1 & Kerajinan Tangan & 29 & 25 & 17 \\
\hline 2 & Fashion & 70 & 36 & 29 \\
\hline \multicolumn{2}{|c|}{ Sumber : Dinas KUMKM dan Perindag Kota Bandung, 2016 }
\end{tabular}

Berdasarkan tabel 1, UMKM kerajinan tangan dan fashion kota Bandung terus mengalami penurunan dari tahun 2016 hingga 2017 jenis usaha kerajinan tangan mengalami penurunan rata-rata sebesar 7\%. Sentra Rajut Binong merupakan salah satu sentra penghasil rajutan di kota Bandung dan sudah memasok hasil rajutan hingga ke Jakarta. Namun banyaknya permintaan rajutan tidak membuat UMKM Sentra Rajut Binong dapat mengembangkan usahanya. UMKM Sentra Rajut Binong kesulitan dengan ketersediaan modal (Pikiran Rakyat, 2016).

Para pengrajin Binong masih memiliki pola pikir secara tradisional seperti pada tahun 1965, Mereka berpendapat dimana konsumen yang datang ke produsen. Hal ini dilatar belakangi kondisi tahun 1956, dimana para produsen tidak perlu melakukan pemasaran secara intensif karena konsumen datang langsung ke produsen. Pola bisnis yang demikianlah yang masih digunakan oleh pelaku usaha UMKM hingga saat ini membuat pelaku usaha tidak berorientasi ke masa depan dan kurang melakukan kegiatan pemasaran . Mereka menjalankan aturan bisnis yang sama ketika sentra Binong Jati masih berjaya, padahal cara-cara berbisnis demikian dinilai sudah tidak sesuai lagi dengan kondisi pasar dimana pesaing bisnis yang harus menawarkan produk ke konsumen.

Perdagangan bebas ASEAN-China (ACFTA) memberikan dampak terhadap penurunan produksi pakaian rajut di Binong Kota Bandung. Produksi pakaian rajut di Binong mengalami penurunan hingga 50 persen (Pikiran Rakyat, 2010). Di berlakukannya perjanjian perdagangan membuat produk-produk dari luar negeri mudah masuk ke Indonesia sehingga persaingan lebih ketat. Produk-produk dari luar negeri umumnya lebih murah dibandingkan dengan produk-produk UMKM sehingga konsumen lebih banyak memilih produk impor yang lebih murah. Produk-produk impor yang lebih murah dibandingkan dengan produk UMKM membuat turunnya permintaan terhadap produk UMKM sehingga produksi barang pun ikut turun seperti contohnya pada rajut Binong yang mengalami penurunan produksi hingga $50 \%$ sejak diberlakukannya perjanjian perdagangan ASEAN-China yang mulai diberlakukan pada tahun 2015.

Dari penjabaran pada latar belakang dapat ditarik kesimpulan bahwa pemasaran yang dilakukan oleh UMKM Sentra Rajut Binong masih kesulitan dalam memasarkan produk-produknya dan kalah dalam daya saing. Berdasarkan paparan tersebut, tujuan penelitian ini adalah menganalisis pengaruh pemasaran kewirausahaan terhadap daya saing UMKM di Kota Bandung.

\section{Kajian Literatur}

\subsection{Usaha Mikro Kecil Menengah (UMKM)}

UMKM merupakan industri penggerak perekonomian negara yang berperan seperti pengurangan pengangguran, peningkatan lapangan kerja, pembangunan perekonomian daerah, dan peningkatan 
ekspor barang-barang (Hadiyati,2009). Menurut Undang-Undang Nomor 20 Tahun 2008 tentang Usaha Mikro, Kecil, dan Menegah bahwa UMKM dikelompokan berdasarkan aset dan omzet. Berikut ini penjelasan lebih rinci tentang usaha mikro, kecil, dan menengah :

1. Usaha yang dikategorikan mikro adalah usaha yang memiliki penjualan rata-rata perbulan $\mathrm{Rp}$ 300.000 .

2. Usaha yang dikategorikan dalam usaha kecil dengan penjualan rata-rata perbulan lebih dari Rp 300.000-Rp 2.500.000.

3. Usaha yang dikategorikan dalam menengah dengan penjualan rata-rata perbulan lebih dari Rp 2.500.000-Rp 50.000.000.000.

Menurut Badan Pusat Statistika, Usaha Mikro, Kecil, Menengah memiliki kriteria berdasarkan jumlah tenaga kerja yaitu :

1. Usaha yang dikategorikan dalam usaha mikro memiliki pekerja sampai dengan 4 orang.

2. Usaha yang dikategorikan dalam usaha kecil memiliki pekerja sebanyak 5-19 orang.

3. Usaha yang dikategorikan dalam usaha menengah memiliki pekerja sampai dengan 20-99 orang.

\subsection{Pemasaran Kewirausahaan}

Pemasaran kewirausahaan merupakan ilmu yang memadukan antara ilmu kewirausahaan dan ilmu pemasaran (Slamet et al., 2016:83). Biasanya pemasaran kewirausahaan menggunakan teknik interaktif yaitu pemasaran dari mulut ke mulut. Seperti yang dikutip pada Hadiyati (2009) pemasaran kewirausahaan adalah pemasaran yang dilakukan dari mulut ke mulut,biasanya dilakukan oleh personal tetapi secara informal. Pemasaran yang dilakukan secara mulut ke mulut yang dilakukan langsung oleh pemilik usaha bertujuan menjadi sumber utama dari ide inovatif yang bersumber langsung dari pelanggan.

Dikutip dari Stokes (2000) fokus dari pemasaran kewirausahaan adalah memproduksi barang sesuai dengan permintaan pelanggan serta lebih berinovasi pada produk. Berikut ini dimensi pemasaran kewirausahaan menurut Stokes (2000) :

1. Konsep

2. Strategi

3. Metode

4. Intelejensi Pasar

Perusahaan dituntut untuk melakukan pengembangan produk, mencari cara yang baru untuk memenuhi kebutuhan para pelanggannya, serta terus melakukan inovasi (Dhewanto, 2013). Sarma (dalam Lina, 2017) entrepreneurial sangat erat berkaitan dengan inovasi dan kreativitas. Sebuah perusahaan dapat maju dengan mengembangkan produknya didasarkan pada inovasi dan kreativitas.

Bjerke dan Hultman (dalam Septiani et al., 2013) Pemasaran kewirausahaan lebih cocok untuk perusahaan kecil menengah karena perusahaan tersebut bisa berkembang melalui cara-cara kewirausahaan. UMKM dinilai lebih cocok mengunakan pemasaran kewirausahaan karena UMKM lebih berfokus pada perencanaan keuangan dibandingkan dengan rencanan pemasaran (Barret \& Sexton dalam Slamet dkk,2016:83). Pemasaran kewirausahaan menggunakan elemen kewirausahaa dalam pemasaran seperti manajemen resiko, inovasi, proaktif untuk memperoleh dan mempertahankan pelanggan (Schindehutte et al., 2002).

\subsection{Daya Saing}

Daya saing merupakan suatu cara yang dilakukan agar perusahaan pesaingnya tidak dapat meniru kelebihan perusahaan (Rachma, 2015:10). Porter (1990) menjelaskan kemampuan perusahaan untuk memproduksi dan menjual produk yang sebanding dengan lebih efisien daripada pesaingnya. Perusahaan juga harus memiliki kemampuan untuk memenuhi harapan pelanggan, melalui penyediaan produk atau layanan yang unik.

Menurut Zonooz et al. (2011) daya saing perusahaan digunakan untuk pertumbuhan dan kelangsungan hidup UMKM, memperoleh dan memanfaatkan pengetahuan, kapasitas serap perusahaan, pengetahuan eksternal dari lingkungan dan kemampuan kombinatif, dan mengeksplorasi pengetahuan yang ada. Sumihardjo (dalam Ramadhani \& Arifin, 2013) sebuah organisasi atau kelompok akan menjadi unggul menggunakan kelebihan dari kelompok tersebut. Menurut Feurer dan Chahabaghi (dalam Man et al., 2002) daya saing merupakan interaksi antara tingkat pelanggan dengan 
para pemilik perusahaan melalui peningkatan kemampuan organisasi, penawaran dan potensi, serta kemampuan organisasi untuk bertindak dan bereaksi melalui kekuatan keuangannya. Salah satu faktor yang mempengaruhi daya saing UMKM adalah daya inovasi dan kemampuan teknologi yang dimiliki suatu perusahaan (Angkasa et al., 2012). Dimensi daya saing yang dikemukakan oleh Porter (1980) :

1. Faktor kondisi

2. Strategi perusahaan, struktur, dan persaingan

3. Kondisi permintaan

4. Industri pendukung dan industri terkait

\section{Metode Penelitian}

\subsection{Populasi dan Sampel}

Pendekatan populasi yang peneliti pakai adalah populasi pemilik usaha Sentra Rajut Binong sebanyak 290 usaha. Dalam penelitian ini penulis mengambil sampel dengan menggunakan accidental sampling, yaitu teknik penentuan sampel berdasarkan kebetulan, yaitu siapa saja yang secara kebetulan/tidak sengaja bertemu dengan peneliti dapat digunakan sebagai sampel, bila dipandang orang yang kebetulan ditemui itu cocok sebagai sumber data (Sugiyono, 2017:144).

\subsection{Teknik Pengumpulan Data}

Teknik pengumpulan data yang akan digunakan adalah kuesioner, yaitu teknik pengumpulan data yang dilakukan dengan cara memberi seperangkat pertanyaan tertulis kepada responden untuk dijawabnya, dapat diberikan secara langsung atau melalui pos atau internet. Jenis kuesioner ada dua, yaitu tertutup dan terbuka. Kuesioner yang digunakan dalam hal ini adalah kuesioner tertutup yakni kuesioner yang sudah disediakan jawabannya, sehingga responden tinggal memilih dan menjawab secara langsung (Sugiyono, 2008: 142). Kuesioner ini ditujukan kepada pemilik usaha rajut di Binong untuk mengetahui persepsi responden tentang pengaruh pemasaran terhadap daya saing UMKM sentra rajut di Binong. Untuk mengukur variabel penelitian yang ditetapkan, peneliti menggunakan Skala Likert. Peneliti menetapkan jawaban dari setiap butir pernyataan yang terdiri dari:

1. Sangat Setuju memiliki nilai lima

2. Setuju memiliki nilai empat

3. Netral memiliki nilai tiga

4. Tidak Setuju memiliki nilai dua

5. Sangat Tidak Setuju memiliki nilai satu

\subsection{Teknik Analisis Data}

Metode analisis data digunakan setelah data terkumpul dari lapangan guna untuk menarik kesimpulan. Metode analisis data pada penelitian ini menggunakan menggunakan analisis regresi dan analisis deskripsi menggunakan software Statistical Product and Service Solution (SPSS) versi 22.0. Metode analisis data yang digunakan pada penelitian ini adalah: analisis deskriptif, analisis regresi sederhana, analisis korelasi, koefisien determinasi, dan uji hipotesis dengan uji $\mathrm{F}$ dan uji t.

\section{Hasil dan Pembahasan}

\subsection{Deskripsi Responden}

Gambar 1 menunjukkan diagram 170 responden yang dikelompokan berdasarkan usia. Usaha Sentra Rajut Binong sebagian besar pemiliknya berusia lebih dari 50 tahun, hal ini dibuktikan dengan hasil kuesioner, usia responden lebih dari 50 tahun memiliki persentase sebesar 38\% berjumlah 64 orang. Persentase kedua terbesar sebanyak 33\% yaitu berusia 41-50 tahun berjumlah 57 orang. Sisanya adalah usia 30-40 tahun dengan presentase sebesar $21 \%$ berjumlah 35 orang dan usia kurang dari 30 tahun sebesar $8 \%$ berjumlah 14 orang. Kesimpulannya pengusaha rajut di Sentra Rajut Binong sebagian besar berusia lebih dari 50 tahun. 


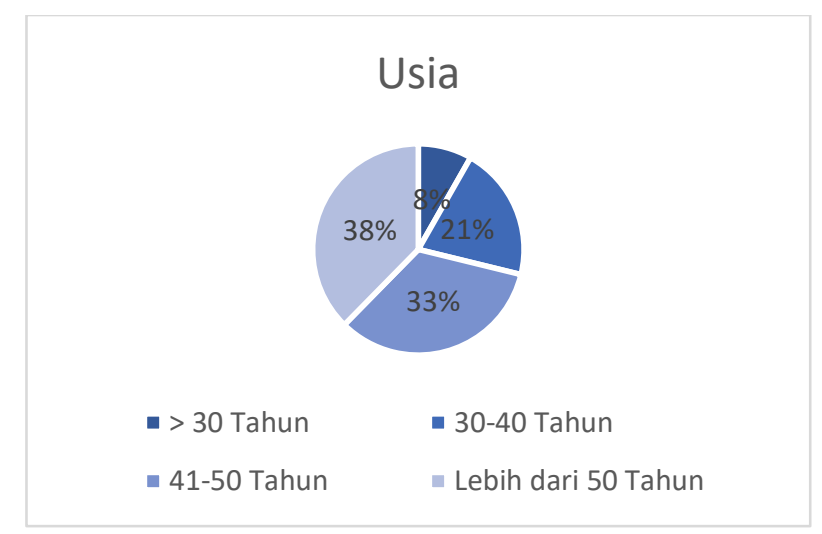

Sumber : Olahan Penulis, 2018

Gambar 1 Responden Berdasarkan Usia

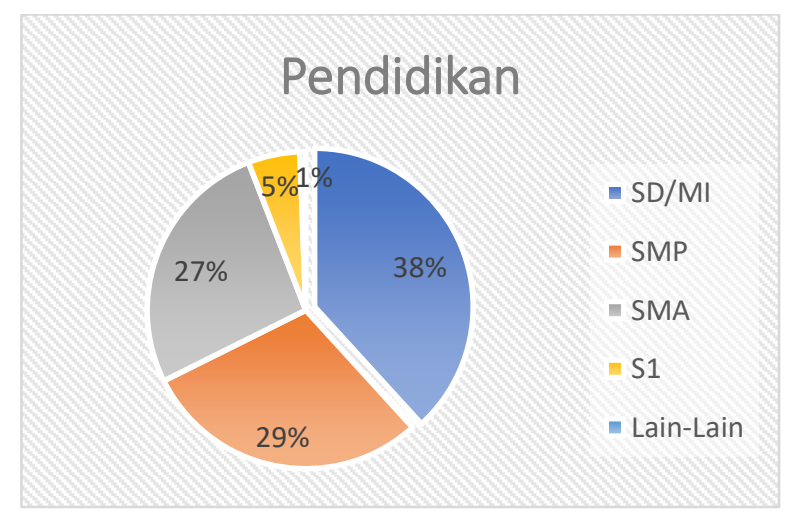

Sumber : Olahan Penulis, 2018

Gambar 2 Responden Berdasarkan Pendidikan

Berdasarkan gambar 2, menunjukkan jumlah responden yang dikelompokkan berdasarkan pendidikan. Responden dengan pendidikan SD sebesar 38\% atau berjumlah 65 orang. Responden dengan pendidikan terakhir SMP 29\% atau berjumlah 50 orang. Responden dengan pendidikan terakhir SMA sebesar 27\% atau berjumlah 24 orang. Responden dengan pendidikan terakhir S1 sebesar $9 \%$ dan pendidikan terakhir lain-lain seperti pelatihan sebesar $1 \%$.

\subsection{Analisis Deskriptif}

Tabel 2 menunjukkan hasil analisis deskripsi variabel pemasaran kewirausahaan yang memiliki empat dimensi. Berdasarkan Tabel 2, pemasaran kewirausahaan memiliki rata-rata sebesar 3,57 yang tergolong kategori tinggi. Berdasarkan hasil rata-rata pemasaran kewirausahaan yang tergolong tinggi menunjukkan pemasaran kewirausahaan UMKM di Kota Bandung tinggi. Dimensi pemasaran variabel pemasaran kewirausahaan yang memiliki 4 dimensi yaitu konsep, strategi, metode, dan intelejensi pemasaran. Dimensi yang memiliki rata-rata yang paling tinggi adalah dimensi konsep sebesar 3,80 dan masuk dalam kategori tinggi. Selain itu dimensi yang memiliki rata-rata terendah adalah dimensi metode sebesar 3,20 dan masuk kategori cukup tinggi. Sedangkan dimensi strategi sebesar 3,69 dan intelejensi pemasaran sebesar 3,47 tergolong dalam kategori tinggi. Penerapan metode yang dilakukan oleh pengusaha rajutan rendah karena sebagian besar pengusaha rajutan sebagian besar merupakan lulusan SD/MI (38\%) dan sebagian besar pengusaha berumur lebih dari 50 tahun sehingga metode yang digunakan masih dengan cara cara pemasaran masih tradisional seperti pemasaran dari mulut ke mulut yang dilakukan langsung oleh pemilik usaha. Pemilik usaha masih terkendala pemasaran karena sebagian besar usaha di Kota Bandung berskala usaha kecil dengan jumlah karyawan 5-19 orang dan mereka tidak menyiapkan dana khusus untuk pemasaran.

Kotler (2008) bahwa konsep pemasaran yang dijalankan oleh wirausaha atau yang dikenal dengan pemasaran kewirausahaan menunjukkan perbedaan dari konsep yang dikemukakan dalam pemasaran konvensional. Dimensi konsep pada Tabel 9, variabel pemasaran kewirausahaan merupakan dasar 
dalam melakukan pemasaran kewirausahaan. Dimensi konsep memiliki rata-rata sebesar 3,80 dan masuk dalam kategori tinggi hal ini terjadi karena para pelaku usaha UMKM selalu membuat konsep terlebih dahulu sebelum melakukan kegiatan produksi maupun kegiatan pemasaran kewirausahaan.

Dimensi konsep pada variabel pemasaran kewirausahaan merupakan dasar dalam melakukan pemasaran kewirausahaan. Dimensi konsep memiliki rata-rata sebesar 3,69 dan masuk dalam kategori tinggi hal ini diterapkan oleh pengusaha UMKM. Para pengusaha selalu membuat strategi agar usahanya terus berkembang dengan cara selalu mengikuti trend selera pelanggan dan memperluas jangkauan pasar. Mayoritas pelaku usaha menjalankan usaha 11-15 tahun sehingga mereka dengan mudah untuk mengetahui model-model yang diminati oleh pelanggan. Para pelaku usaha masuk dalam kategori tinggi karena mereka mampu membuat produk mengikuti selera konsumen tetapi para pelaku usaha masih kesulitan dalam mencari daerah pemasaran baru.

Para pengusaha UMKM terbukti menerapkan metode-metode yang sebelumnya dikonsep dalam membuat strategi agar usahanya terus maju. Dimensi konsep memiliki rata-rata sebesar 3,20 dan masuk dalam kategori tinggi. Pada variabel pemasaran kewirausahaan, dimensi metode memiliki rata-rata paling rendah dibandingkan dengan dimensi yang lain. Para pengrajin rajutan masih berfokus pada produksi dan hanya menjalin komunikasi dengan pelanggan baru. Dilihat dari hasil rata-rata indikator, komunikasi dengan pelanggan baru memiliki rata-rata paling rendah yaitu 3,07 yang berarti pelaku usaha masih memiliki kesulitan yaitu metode untuk berkomunikasi dengan pelanggan baru.

Dimensi intelejensi pasar memiliki rata-rata sebesar 3,80 dan masuk dalam kategori tinggi. Para pengrajin di Sentra Rajut Binong, contohnya, mudah dalam mendapatkan bahan baku karena bahan baku rajutan banyak dijual di lingkungan sehingga memudahkan para pelaku usaha. Selain itu para pelaku usaha di Kota Bandung mampu menciptakan hubungan dengan instansi pemerintah dan usaha lain di sekitar sehingga dapat mencari informasi mengenai perkembangan usaha yang ditekuni. Namun pelaku usaha di Kota Bandung masih kesulitan dalam konsistensi bahan baku. Fakta dilapangan, terdapat banyak penjual bahan baku tetapi harga bahan baku yang harganya terus naik menjadi permasalahan para pengusaha rajutan.

Tabel 2 Deskriptif Statistik Variabel Pemasaran Kewirausahaan

\begin{tabular}{|l|r|r|r|r|}
\hline & Minimum & Maximum & Mean & Std. Deviation \\
\hline Konsep & 2 & 5 & 3,80 &, 607 \\
\hline Strategi & 2 & 5 & 3,69 &, 832 \\
\hline Metode & 2 & 5 & 3,20 &, 983 \\
\hline Intelejensi_Pemasaran & 2 & 5 & 3,47 &, 676 \\
\hline Pemasaran_Kewirausahaan & 2 & 5 & 3,57 &, 722 \\
\hline
\end{tabular}

Tabel 3 menunjukkan hasil analisis deskripsi variabel daya saing yang memiliki empat dimensi. Daya saing memiliki rata-rata sebesar 3,92. Dari hasil rata-rata variabel daya saing menunjukkan bahwa daya saing pada UMKM di Kota Bandung tergolong tinggi. Daya saing memiliki empat dimensi yaitu faktor kondisi, strategi perusahaan, kondisi permintaan, dan industri pendukung. Dimensi yang memiliki rata-rata paling tinggi adalah dimensi industri pendukung sebesar 3,97 yang tergolong dalam kategori tinggi. Selain itu terdapat dimensi yang memiliki rata-rata paling rendah yaitu dimensi strategi perusahaan sebesar 3,93 dan tergolong dalam kategori tinggi. Sedangkan rata-rata dimensi faktor kondisi sebesar 3,94 dan rata-rata kondisi permintaan sebesar 3,96 yang tergolong dalam kategori tinggi. Dalam daya saing, pengusaha di Kota Bandung masih rendah dalam strategi perusahaan. Latar belakang pendidikan pemilik usaha rajutan yang sebagian besar merupakan lulusan SD/MI sehingga membuat para pelaku usaha kurang mematangkan strategi perusahaan untuk bisa bersaing dengan produk lain. Kurangnya strategi perusahaan juga memperkecil kesempatan untuk berkembangnya setiap usaha. 
Tabel 3 Deskriptif Statistik Variabel Daya Saing

\begin{tabular}{|l|r|r|r|r|}
\hline & Minimum & Maximum & Mean & Std. Deviation \\
\hline Faktor_Kondisi & 3 & 4 & 3,94 &, 237 \\
\hline Strategi_Perusahaan & 3 & 5 & 3,93 &, 448 \\
\hline Kondisi_Permintaan & 3 & 5 & 3,96 &, 545 \\
\hline Industri_Pendukung & 3 & 5 & 3,97 &, 318 \\
\hline Daya_Saing & 3 & 5 & 3,92 &, 335 \\
\hline
\end{tabular}

Dimensi faktor kondisi pada variabel pemasaran kewirausahaan merupakan dasar dalam melakukan pemasaran kewirausahaan. Dimensi konsep memiliki rata-rata sebesar 3,94 dan masuk dalam kategori tinggi yang berarti faktor kondisi seperti perlatan mesin mendukung para pelaku usaha UMKM di Kota Bandung dalam daya saing dengan produk-produk lain. Namun faktor kondisi seperti akses jalan masih banyak kerusakan, hal ini memungkinkan menghambat proses pengiriman barang dan berkurangnya pelanggan karena akses jalan yang kurang bagus. selain itu, sumber daya manusia atau para pekerja sulit didapatkan sehingga memengaruhi penurunan produksi. Hal yang sangat mempengaruhi dalam penurunan daya saing teknologi karena sebagian besar pengusaha berusia lebih dari 50 tahun dan pendidikan terkahir SD/MI sehingga mereka gagap teknologi. Pada zaman sekarang teknologi merupakan hal yang paling utama dalam bidang apapun termasuk pengembangan usaha sehingga membuat pengusaha di Kota Bandung kalah daya saing karena kurangnya penguasaan teknologi.

Dimensi strategi perusahaan pada variabel daya saing memiliki rata-rata sebesar 3,93 dan masuk dalam kategori tinggi hal ini terjadi karena para pelaku UMKM di Kota Bandung mampu bersaing dengan produk lain dengan cara selalu mencari desain yang selalu diminati dan mengelola bisnis dengan pengetahuan. Dalam manajerial atau pengelolaan bisnis, para pengusaha tinggi, dilihat dari rata-rata indikator manajerial sebesar 4,04. Dari tingginya indikator manajerial dapat dilihat bahwa daya saing dengan strategi perusahaan melalui manajerial. Kemampuan perusahaan untuk membuat keberagaman produk yang sesuai dengan minat konsumen yang berbeda-beda dan selalu membaca peluang pasar agar selalu dapat bersaing dengan perusahaan yang sejenis juga salah satu strategi-strategi untuk meningkatkan daya saing. Produk-produk UMKM di Kota Bandung belum mampu bersaing dengan produk sejenis karena rendahnya inovasi produk rajutan dari pengusaha, hal ini dapat dilihat dari rendahnya rata-rata dari indikator inovasi produk sebesar 3,36.

Dimensi kondisi permintaan merupakan salah satu variabel daya saing yang digunakan dalam penelitian ini. Dimensi konsep memiliki rata-rata sebesar 3,96 dan masuk dalam kategori tinggi. Dalam variabel daya saing, dimensi faktor permintaan merupakan dimensi yang memiliki rata-rata tertinggi, hal ini berarti kondisi permintaan yang tinggi terhadap produk rajutan, meskipun banyak produk impor dipasaran tetapi konsumen masih memiliki minat yang tinggi terhadap produk rajutan terutama produk rajutan Sentra Rajut Binong. Kondisi permintaan yang masih tergolong tinggi namun tidak mempengaruhi pertumbuhan permintaan. Berdasarkan rata-rata indikator dari dimensi kondisi permintaan, indikator pertumbuhan memiliki indikator yang paling rendah yaitu sebesar 3,79 yang artinya meskipun kondisi permintaan naik tetapi tidak dapat dipastikan akan mempengaruhi pertumbuhan permintaan.

Dimensi industri pendukung dan terkait merupakan salah satu variabel daya saing yang digunakan dalam penellitian ini. Dimensi konsep memiliki rata-rata sebesar 3,92 dan masuk dalam kategori tinggi karena para pelaku usaha mudah dalam mendapatkan bahan baku sehingga produksi terus berjalan lancar. Dalam variabel daya saing, industri pendukung dan industri terkait memiliki rata-rata terendah dibandingkan dengan dimensi lain. Selain itu para pelaku usaha juga mendapat kemudahan dalam akses peminjaman modal dari bank sehingga para pelaku usaha UMKM mudah untuk mengembangkan usaha dengan tambahan modal dari bank namun tingginya suku bunga membuat para pengrajin usaha mengandalkan modal pribadi. Dari dimensi faktor kondisi berupa indikator akses jalan juga belum mendukung sehingga menghambat pengiriman barang.

\subsection{Analisis Regresi Sederhana}

Tabel 4 Menunjukkan hasil dari regresi sederhana pada penelitian ini. Angka koefisien diartikan bahwa setiap penambahan dalam melakukan pemasaran kewirausahaan maka daya saing akan meningkat 
sebesar 0,283. Karena koefisien regresi bernilai positif maka dengan demikian dapat diartikan bahwa pemasaran kewirausahaan berpengaruh positif terhadap daya saing, sehingga didapatkan persamaan regresinya adalah $\mathrm{Y}=50,720+0,283 \mathrm{X}$. Tabel 4 diketahui diketahui bahwa nilai signifikan (Sig.) sebesar 0,000 lebih kecil dari probabilitas yaitu 0,05 sehingga dapat disimpulkan bahwa Ha diterima yang berarti terdapat pengaruh pemasaran kewirausahaan terhadap daya saing.

Tabel 4 Hasil Regresi Sederhana

\begin{tabular}{|l|l|r|r|r|c|}
\hline \multirow{2}{*}{ Model } & \multicolumn{2}{|c|}{ Unstandardized Coefficients } & \multirow{2}{*}{} & \multirow{2}{*}{ Sig. } \\
\cline { 2 - 4 } 1 & B & Std. Error & t & B \\
\cline { 2 - 4 } & X & 50,720 & 1,437 & 35,294 & 0,000 \\
\cline { 2 - 4 } & & 0,283 & 0,027 & 10,631 & 0,000 \\
\hline
\end{tabular}

a. Dependent Variable: Y

Dari hasil persamaan regresi diatas dapat disimpulkan bahwa nilai positif $(0,283)$ yang terdapat pada koefisien regresi menggambarkan bahwa arah hubungan antara variabel pemasaran kewirausahaan dan daya saing adalah searah, setiap penambahan 1 unit variabel pemasaran kewirausahaan maka akan meningkatkan nilai dari variabel daya saing sebesar 0,283.

Tabel 5 menunjukkan hasil korelasi pada penelitian untuk mengukur pengaruh variabel pemasaran kewirausahaan terhadap daya saing. Dari Tabel 5 diketahui bahwa responden sebanyak 170 dihasilkan nilai kolerasi sebesar 0,634 . Untuk melakukan interpretasi kekuatan hubungan antara dua variabel dilakukan dengan melihat angka koefisien kolerasi hasil perhitungan terdapat korelasi sebesar 0,634 atau terdapat korelasi yang kuat antara variabel pemasaran kewirausahaan dan variabel daya saing. Pada angka korelasi juga menunjukkan nilai positif yang dapat diartikan bahwa adanya korelasi positif antara variabel pemasaran kewirausahaan dan variabel daya saing, yang berarti setiap kenaikan dan penurunan nilai-nilai variabel pemasaran kewirausahaan akan diikuti dengan kenaikan dan penurunan variabel daya saing.

Tabel 5 Hasil Korelasi

\begin{tabular}{|l|l|r|}
\hline \multicolumn{2}{|c|}{} & Pemasaran Kewirausahaan \\
\hline Daya Saing & Pearson Correlation & $0,634^{* *}$ \\
\cline { 2 - 3 } & Sig. (2-tailed) & 0,000 \\
\cline { 2 - 3 } & $\mathrm{N}$ & 170 \\
\hline
\end{tabular}

Nilai R Square yang digunakan, diambil dari tabel model summary dalam Tabel 6. Nilai R Square pada tabel 6 adalah sebesar 0.402 artinya $40.2 \%$. Variasi variabel daya saing yang dapat dijelaskan oleh variabel pemasaran kewirausahaan adalah sebesar $40.2 \%$, sedangkan sisanya sebesar $59.8 \%$ dijelaskan oleh variabel lainnya yang tidak terdapat pada penelitian ini. Sehingga pemasaran kewirausahaan dan daya saing berpengaruh sebanyak $40.2 \%$ terhadap daya saing, sedangkan faktor lainnya adalah 59.8\% dipengaruhi oleh faktor-faktor yang tidak diteliti.

Tabel 6 Model Summary

\begin{tabular}{|l|c|r|r|r|}
\hline Model & R & R Square & Adjusted R Square & Std. Error of the Estimate \\
\hline 1 & $0,634^{\mathrm{a}}$ & 0,402 & 0,399 & 3,088 \\
\hline
\end{tabular}

a. Predictors: (Constant), $\mathrm{X}$

\subsection{Uji Hipotesis}

Uji $\mathrm{F}$ dalam penelitian ini bertujuan untuk mengetahui secara bersama-sama pengaruh pemasaran kewirausahaan terhadap daya saing pada Tabel 7. Tabel 7 menunjukkan nilai F hitung sebesar 113.014 dan nilai Sig.pada tabel anova sebesar 0.000. Nilai F hitung tersebut kita bandingkan dengan $F$ tabel yang sudah dihitung yaitu sebesar 3.90, terlihat bahwa nilai $F$ hitung lebih besar dari $F$ tabel yang artinya ha atau hipotesis alternative yang digunakan diterima. 
Tabel 7 Hasil Uji F

\begin{tabular}{|c|c|c|c|c|c|}
\hline Model & Sum of Squares & $\mathrm{df}$ & Mean Square & $\mathrm{F}$ & Sig. \\
\hline Regression & 1077,955 & 1 & 1077,955 & 113,014 & $0,000^{\mathrm{b}}$ \\
\hline Residual & 1602,422 & 168 & 9,538 & & \\
\hline Total & 2680,376 & 169 & & & \\
\hline
\end{tabular}

Uji t ini dimaksudkan untuk mengetahui pengaruh secara parsial (individu) variabel-variabel independen yakni pemasaran kewirausahaan terhadap variabel dependen yaitu daya saing. Pengujian ini menggunakan tabel coefficients yang akan disajikan dalam Tabel 8. Uji t yang dilakukan dalam penelitian ini dengan membandingkan nilai t hitung dengan $t$ tabel yang telah diperhitungkan, dan tabel t untuk penelitian ini yaitu sebesar 1.974. Dan cara kedua dengan menggunakan nilai Sig yang terdapat didalam tabel, kemudian dibandingkan dengan tingkat signifikan sebesar 0.05. Jika nilai Sig lebih besar dari tingkat signifikan maka $\mathrm{H0}$ akan diterima, sedangkan jika nilai Sig lebih kecil dari 0.05 maka Ha akan diterima dan $\mathrm{h} 0$ ditolak.

Dari hasil perhitungan, variabel pengalaman kerja memiliki t hitung sebesar 10,631 yang berarti lebih besar dibandingkan dengan t tabel sebesar 1.974. dan nilai Sig sebesar 0.000 yang berarti lebih kecil dibandingkan dengan tingkat signifikansi sebesar 0.05. Maka dapat disimpulkan bahwa ha diterima yang menunjukkan bahwa pemasaran kewirausahaan merupakan faktor yang mempengaruhi daya saing.

Tabel 8 Hasil Uji t

\begin{tabular}{|l|l|r|r|r|r|}
\hline \multirow{2}{*}{ Model } & \multicolumn{2}{|c|}{ Unstandardized Coefficients } & & \multirow{2}{*}{ Sig. } \\
\cline { 2 - 4 } & \multicolumn{1}{|c|}{ B } & Std. Error & \multicolumn{1}{c|}{. } & \multicolumn{1}{c|}{ Sig } \\
\hline \multirow{2}{*}{1} & (Constant) & 50,720 & 1,437 & 35,294 & 0,000 \\
\cline { 2 - 5 } & Pemasaran Kewirausahaan & 0,283 & 0,027 & 10,631 & 0,000 \\
\hline
\end{tabular}

\subsection{Pembahasan}

Berdasarkan hasil analisis yang telah diuraikan di atas diperoleh hasil bahwa variabel pemasaran kewirausahaan berpengaruh signifikan terhadap variabel daya saing. Hal tersebut ditunjukkan dari hasil analisis kolerasi product moment sebesar 0,634 atau terdapat korelasi yang kuat antara variabel pemasaran kewirausahaan dan variabel daya saing. Dengan koefisien determinasi sebesar 0,402 atau 40,2\% maka berpengaruh positif, artinya jika semakin tinggi para pelaku usaha rajutan di Sentra Rajut Binong melakukan pemasaran kewirausahaan maka semakin tinggi pula daya saing. Sedangkan 40,2\% merupakan faktor yang mempengaruhi variabel pemasaran kewirausahaan terhadap daya saing dan $59,8 \%$ dari faktor lain yang tidak diteliti oleh peneliti.

Dari hasil analisi uji $\mathrm{F}$ dan uji t diketetahui bahwa ada pengaruh yang signifikan variabel pemasaran kewirausahaan dan variabel daya saing, hal ini dibuktikan dengan hasil perhitungan nilai $\mathrm{F}$ hitung tersebut kita bandingkan dengan $\mathrm{F}$ tabel yang sudah dihitung yaitu sebesar 3.90, terlihat bahwa nilai $\mathrm{F}$ hitung lebih besar dari $\mathrm{F}$ tabel yang artinya ha atau hipotesis alternative yang digunakan diterima. Selain itu, hasil uji t sebesar 10,631, sedangkan pada t tabel adalah 1,974 pada taraf signifikansi $5 \%$ yang berarti bahwa Ha diterima. Selain itu juga diperoleh persamaan regresi $\mathrm{Y}=50,720+0,283 \mathrm{X}$ dapat disimpulkan bahwa nilai positif $(0,283)$ yang terdapat pada koefisien regresi menggambarkan bahwa arah hubungan antara variabel pemasaran kewirausahaan dan daya saing adalah searah, setiap penambahan 1 unit variabel pemasaran kewirausahaan maka akan meningkatkan nilai dari variabel daya saing sebesar 0,283. Sehingga dapat disimpulkan dari hasil uji t, terdapat pengaruh antara variabel Y terhadap Variabel $\mathrm{X}$ atau Ha diterima yaitu terdapat pengaruh pemasaran kewirausahaan terhadap daya saing pada pelaku usaha.

\section{Kesimpulan}

Hasil penelitian menunjukkan pemasaran kewirausahaan UMKM di Kota Bandung berada di level tinggi. Pemasaran kewirausahaan yang dilakukan oleh para pelaku usaha terlihat dari tidak adanya dana 
khusus yang digunakan untuk pemasaran dan kegiatan promosi serta tidak adanya tenaga khusus untuk melakukan pemasaran. Sebagian besar pelaku usaha menggunakan pemasaran yang dilakukan langsung oleh pemilik usaha kepada pelanggan guna menekan biaya pemasaran serta bertujuan mencari dari ide inovatif yang bersumber langsung dari pelanggan. Menurut Septiani (2013) Pemasaran kewirausahaan merupakan pemasaran yang sesuai dengan permasalahan yang sering dihadapi oleh UMKM seperti kurangnya sumber daya manusia, terbatasnya modal dan kurangnya pengetahuan dan keterampilan.

Hasil rata-rata variabel daya saing menunjukkan bahwa daya saing pada UMKM di Kota Bandung tergolong tinggi karena didukung oleh industri pendukung dan industri terkait seperti mudah dalam mendapatkan bahan baku sehingga produksi terus berjalan lancar. Selain itu keahlian dalam melakukan strategi perusahaan tergolong dalam kategori tinggi membuat tingginya daya saing. Namun, dalam inovasi produk dari produk UMKM di Kota Bandung belum mampu bersaing dengan produk sejenis karena rendahnya inovasi dari pengusaha, hal ini dapat dilihat dari rendahnya rata-rata dari indikator inovasi produk.

Pengaruh pemasaran kewirausahaan terhadap daya saing UMKM di Kota Bandung memiliki pengaruh yang signifikan, hal ini terlihat dari hasil koefisien regresi menggambarkan bahwa arah hubungan antara variabel pemasaran kewirausahaan dan daya saing adalah searah dan terdapat pengaruh pemasaran kewirausahaan terhadap daya saing pada pelaku usaha.

\section{Daftar Pustaka}

Badan Pusat Statistika. (2018). Pengertian Usaha Mikro,Kecil dan Menengah. https://www.bps.go.id/subject/35/usaha-mikro-kecil.html [diakses 20 Februari 2018]

Cohen, L, Manion, L, \& Marrison, K. (2017). Research Methods in Education. New York : Routledge Departemen Perdagangan Republik Indonesia. (2008). Usaha Kecil dan Menengah. www.depkop.go.id Dhewanto, W. (2014). Manajemen Inovasi Peluang Sukses Menghadapi Perubahan. Yogyakarta: Penerbit Andi

Fitriati, F. (2015). Menguak Daya Saing UMKM Industri Kreatif. Jakarta: Yayasan Pustaka Obor Indonesia

Hadiyati, E. (2009). Kajian Pendekatan Pemasaran Kewirausahaan dan Kinerja Penjualan Usaha Kecil. Jurnal Manajemen dan Kewirausahaan, 11 (2), 183-192.

Indrawati. (2015). Metode Penelitian Manajemen dan Bisnis Konvergensi Teknologi Komunikasi dan Informasi. Bandung: PT Refika Aditama

Kotler, P. (2008). Prinsip-Prinsip Pemasaran Edisi 12. Jakarta: Erlangga

Lina. (2017). Analisis Pengaruh Pemasaran Kewirausahaan Terhadap Daya Saing Industri Kerupuk Kemplang Di Palembang (Studi Kasus Pembuatan Kerupuk Kemplang Di Kelurahan 23 Ilir Palembang). Seminar Nasional Teknologi Informasi, Bisnis, dan Desain. ISBN :978-602-74634-17

PERDA NO. 2. (2009). Rencana Pembangunan Jangka Menengah kota Bandung. http://www.bphn.go.id/data/documents/09pdkotabandung009.pdf

Schindehutte, Morris, M.H, \& LaForge, R.W. 2002. Entrepreneurial marketing: a construct for integrating emerging entrepreneurship and marketing perspectives. Journal of Marketing Theory and Practice, 10 (4), 1-19.

Septiani, S, Sarma, M, \& Limbong,W.H. 2013. Pengaruh Entrepreneurial Marketing Dan Kebijakan Pemerintah Terhadap Daya Saing Industri Alas Kaki di Bogor. Jurnal Manajemen dan Organisasi, 4 (2).

Pikiran Rakyat Online. (2016). Ini Alasan UMKM JABAR sulit maju. http://www.pikiranrakyat.com/ekonomi/2016/05/11/ini-alasan-umkm-jabar-sulit-maju-368842 [Diakses 18 Februari 2018]

Stokes, D. (2000). Putting Entrepreneurship into Marketing: The Processes of Entrepreneurial Marketing. Journal of Research in Marketing \& Entrepreneurship, 2 (1).

Stokes, D. (2000). Entrepreneurial Marketing: A Conceptualisation from Qualitative Research. Qualitative Market Research, 3 (1), 47-54.

Sugiyono. (2008). Metode Penelitian Kuantitatif, Kualitatif dan R \& D. Bandung: Alfabeta

Sugiyono. (2011). Metode Penelitian Kuantitatif, Kualitatif dan R \& D. Bandung: Alfabeta 
Tyas, A \& Safitri, V. (2014). Penguatan Sektor UMKM sebagai Strategi Menghadapi MEA 2015. Jurnal Ekonomi, 5 (1).

Undang-Undang No. 2 Tahun 2008 tentang Usaha Mikro, Kecil, dan Menengah. (2008). www.bi.go.id/id/tentangbi/uubi/Documents/UUTahun2008UMKM.pdf [Diakses 15 Maret 2018]

*Email korespondensi:

fellyanaindri@gmail.com 